
фибринообразования и фибриностабилизации

ГОУ ВПО "Алтайский государственный медицинский университет" Росздрава, г. Барнаул

\author{
Ya.N.Shoikhet, A.V.Lepilov, Yu.G.Motin, A.P.Bochkarev
}

\title{
Morphological and structural variants of cellular and stromal interaction in a focus of destruction in acute lung abscess and lung gangrene in term of formation and stabilisation of fibrin-associated processes
}

\begin{abstract}
Summary
Purulent and destructive lung diseases are often complicated by loss of anatomic structure of lung tissue, development of lung cirrhosis with subsequent respiratory and heart failure. We performed pathomorphological examination of operational and post mortem lung tissue specimens from 116 inpatients of 25 to 78 years of age with acute lung abscess or lung gangrene who was treated at a pulmonology center from 1999 to 2005 . Acute lung inflammation tending to suppuration was characterized by pronounced cell reaction with no "fibrin blockage" and resulted in extended histolysis and abscess formation. "Young" fibrin was often found. Microvessels were fully passable, full-blooded with no fibrin into lumen. At subacute stage, fibrin was "maturing" with subsequent organization and growth of granulated tissue. Clinically, there were sequestered lung abscesses. Massive deposits of "young" and "maturing" fibrin formed "fibrin cocoon" with macrophages and neutrophils bricked up inside. Cell reaction was weak. There were swelling and desquamation of endothelium of microvessels, massive fibrin deposits into vessel lumen and prominent perivascular impregnation with fibrin. This pathological variant could lead to formation of abscess or pulmonary fibrosis with carnification. In cases of massive subtotal or total, often bilateral lung injury with weak delimiting of purulent and destructive process massive destructive zones with resting lung parenchyma faintly impregnated with fibrin were seen. There were no features of fibrin deposition inside microvessels. Functional activity of neutrophils and macrophages was greatly decreased. Therefore, the most favourable pathohistological variant appears to be formation of fibrin blockage consisted of "young" fibrin deposits; prominent cell reaction and absence of microcirculatory block. Structural changes of cells and stroma should be considered during pathological examination in order to provide optimal treatment strategy.
\end{abstract}

\section{Резюме}

Разрешение гнойно-деструктивных процессов в легочной ткани нередко сопровождается потерей анатомических структур с формированием пневмоцирроза и развитием легочно-сердечной недостаточности. Проведено патоморфологическое исследование операционного и секционного материала легких 116 пациентов в возрасте от 25 до 78 лет с острыми абсцессами и гангреной легких, находившихся на стационарном лечении в пульмонологическом центре с 1999 г. по 2005 г. При остром воспалении с тенденцией к нагноению в очаге повреждения легочной ткани определялось большое количество клеточных популяций без образования "фибринового блока", что вело к распространенному гистолизу с формированием абсцесса. Часто определялся очень "молодой" фибрин. Сосуды микроциркуляторного русла были проходимы практически на всем протяжении и характеризовались полнокровием без признаков фибринообразования. В подострый период развития патологического процесса происходило "созревание" фибрина с последующей организацией и разрастанием грануляционной ткани. Клинически у больных выявлялись абсцессы легкого с секвестрацией. Массивные отложения "молодого" и "созревающего" фибрина формировали своеобразный "фибриновый кокон" с "вмонтированными" внутрь макрофагами и нейрофилами и сниженной клеточной реакцией. В сосудах микроциркуляторного русла отмечалось набухание и слущивание эндотелия, массивное отложение фибрина с нарушением проходимости сосудов на фоне выраженной периваскулярной фибринации тканей. В подобном случае возможно развитие как абсцесса, так и пневмофиброза с тенденцией к карнификации. При обширном субтотальном и тотальном, часто двустороннем, поражении легочной ткани со слабо выраженной тенденцией к отграничению гнойно-деструктивного процесса выявлялись обширные зоны деструкции с остатками слабо фибринизированной легочной паренхимы без признаков фибринообразования в сосудах микроциркуляторного русла; функциональная активность нейтрофилов и макрофагов была значительно снижена. Таким образом, наиболее благоприятными вариантами патогистологических изменений следует считать формирование фибринового блока из "молодых" фибриновых депозитов, выраженную клеточную реакцию и отсутствие блокады микроциркуляции. Структурные закономерности клеточно-стромальных преобразований должны учитываться при морфологическом исследовании для выбора правильной тактики лечения данной патологии.

Гнойно-деструктивные заболевания легких (ГДЗЛ) тяжелые, нередко угрожающие жизни осложнения тяжелых форм пневмоний, характеризуюшиеся массивным некрозом и последующим гнойным или гнилостным распадом (деструкцией, лизисом) ле- гочной ткани в результате воздействия возбудителя заболевания [1].

Вследствие роста числа пациентов с острыми нагноениями легких [2, 3] в последние годы, снижения качества жизни больных, частой летальности и 
инвалидности, проблема лечения ГДЗЛ с учетом основных звеньев патогенеза остается актуальной проблемой пульмонологии [4]. Травматичность оперативного лечения (особенно эмпием плевры), переход гнойно-деструктивных процессов в хроническую стадию нередко сопровождаются потерей анатомических структур с последующим формированием пневмоцирроза и развитием легочно-сердечной недостаточности, играющей основную роль в танатогенезе больного. В настоящее время приоритетным направлением является изучение 3 основных звеньев патогенеза, взаимодействие которых и определяет развитие заболевания: нарушение бронхиальной проходимости, развитие острого инфекционного воспалительного процесса в легочной паренхиме и нарушение кровотока, ведущие к деструкции легочной ткани [5].

В генезе микроциркуляторных расстройств в пораженном легком важную роль играет развитие при острых абсцессах и гангрене легких тяжелого эндотелиоза и синдрома диссеминированного внутрисосудистого свертывания крови (ДВС). Блокада микроциркуляции в зоне поражения и интенсивное отложение фибрина как в микрососудах органа, так и в окружающей межуточной ткани легкого приводит не только к ишемическим и воспалительным нарушениям, но и затрудняет доступ лекарственных препаратов в очаг деструкции, что не только снижает эффективность лечения, но и вызывает дестабилизацию клеточно-стромальных взаимодействий в очаге проражения. При этом немалая часть пациентов становятся инвалидами и теряют трудоспособность, поэтому проблема приобретает и социальный характер.

Тем не менее появление фибрина на начальных этапах заболевания имеет и биологическую целесообразность. Доказанным является тот факт, что несостоятельность первичного фибринового блока может привести к прогрессированию воспалительного процесса и вовлечению в него новых анатомических структур легких. Это негативно повлияет на последующие репаративные процессы в силу того, что у респираторных отделов легких форма регенерации преимущественно внутриклеточная [6].

У больных ГДЗЛ количество полиморфноядерных лейкоцитов в бронхоальвеолярных пространствах резко возрастает, а легочных макрофагов уменьшается, что сопровождается значительным повышением протеолитической активности лейкоцитов за счет полинуклеаров и снижением кислородзависимой метаболической активности макрофагов. Подобное изменение функциональной активности фагоцитирующих клеток в ряде случаев приводит к вовлечению в деструктивный процесс здоровых участков легких. По отдельным данным, коррекция метаболической, прокоагулянтной и протеолитической активности фагоцитов в очаге деструкции у больных ГДЗЛ позволяет увеличить число радикально оперируемых больных при одновременном росте удельного веса органосохраняющих операций, снижает частоту послеоперационных бронхолегочных осложнений, летальность и улучшает отдаленные исходы [6].

Таким образом, в развитии и течении ГДЗЛ определяющую роль играет своевременное и полноценное отграничение очага гнойной деструкции фибриновыми депозитами на фоне нормальной функциональной активности фагоцитирующих клеток и проходимого микроциркуляторного русла.

Цель исследования - определить закономерности развития процессов фибринообразования, фибриностабилизации, клеточно-тканевых взаимодействий и функциональной активности клеток при ГДЗЛ.

\section{Материалы и методы}

Проведено патоморфологическое исследование легких (операционный и секционный материал) 116 пациентов в возрасте 25-78 лет с острыми абсцессами и гангреной легких, находившихся на стационарном лечении в пульмонологическом центре многопрофильной больницы в период 1999-2005 гг.

Для оценки характера структурных изменений в паренхиме легких оценивали такие патоморфологические показатели, как отграничение очага деструкции фибриновыми депозитами, функциональную активность фагоцитирующих клеток и их инкорпорацию в "фибриновый блок", проходимость микроциркуляторного русла.

В качестве фиксирующей жидкости использовали 10\%-ный раствор нейтрального формалина. Для патологогистологического исследования 5-6 кусочков забирали из различных гистотопографических зон.

Срезы тканей толщиной 4-6 мкм окрашивали гематоксилином и эозином, пикрофуксином Вейгерта для выявления эластических структур, импрегнировали серебром по методу Гордона-Свита в целях выявления ретикулярной стромы органа, выполняли ШИК-реакцию. Для оценки процессов фибринообразования и фибриностабилизации использовали окраску на фибрин по MSB-методу. Полученные результаты интерпретировали по цветовой гамме: желтое окрашивание фибрина свидетельствовало о раннем сроке его образования (от 0 до 2-4 ч), оранжевое окрашивание наблюдалось в интервале от 4-6 до 20 ч с момента коагуляции, "молодой" фибрин со сроком образования от 20-24 до 48 ч окрашивался в ярко-красный цвет, "созревающий" и "старый" фибрин - соответственно в голубой и синий тона после 48 ч с момента стабилизации белковых депозитов. "Стареющий" фибрин, как правило, являлся необратимым компонентом морфологического субстрата, он не лизировался ферментными препаратами, а подвергался организации с образованием коллагеновых волокон.

Для определения общей функциональной жизнеспособности клеток использовали методику полихромной окраски сафранином-О (Т) по А.Н.Яцковскому [7].

Исследование проводили на основе сопоставления клинических данных, рентгенологической картины 
по историям болезней, рентгенограмм, бронхограмм. В ходе морфометрических исследований использовали графический пакет ImageJ 1.34 [8].

Результаты работы представлены в виде значений $M$ (средняя) $\pm S D$ (стандартное отклонение). Оценку межгрупповых различий проводили по критерию Холма-Сидака при нормальном распределении признака и равенстве дисперсий или по критерию Данна. Статистическую обработку результатов выполняли посредством компьютерной программы SigmaStat 3.5 for Windows, Systat Software, Inc. (США, 2006).

\section{Результаты и обсуждение}

При патоморфологических исследованиях легочной ткани наблюдался полиморфизм светооптической картины, обусловленный мозаичностью деструктивных изменений в легких.

В случаях острого воспаления с тенденцией потенциального нагноения в очаге повреждения легочной ткани определялось большое количество клеточных популяций, преимущественно гематогенного происхождения. Микрососуды были проходимы практически на всем протяжении. "Молодой" фибрин не образовывал своеобразного фибринового блока, что в условиях прогрессирования патологического процесса, в сочетании с ДВС-синдромом и на пике протеолитической активности лейкоцитов вело к распространенному гистолизу с формированием абсцесса. В остром периоде воспаления часто наблюдалась картина образования очень "молодого" фибрина, сроком до 12-24 ч (рис. 1).

Формировалась своеобразная сеть из фибрина, где располагались преимущественно полиморфноядерные лейкоциты.

В $36 \%$ случаев (42 больных из 116) определялись четко отграниченные фибрином (сроком от 2-6 до 24-48 ч) очаги острой гнойной деструкции с большим количеством некротизированных нейтрофилов и макрофагов, а также гемолизированных эритроцитов. Содержащиеся в очаге хаотично расположенные нити фибрина имели срок фибринообразования от 1-2 до 24-36 ч. Определялись единичные ретикуляр-

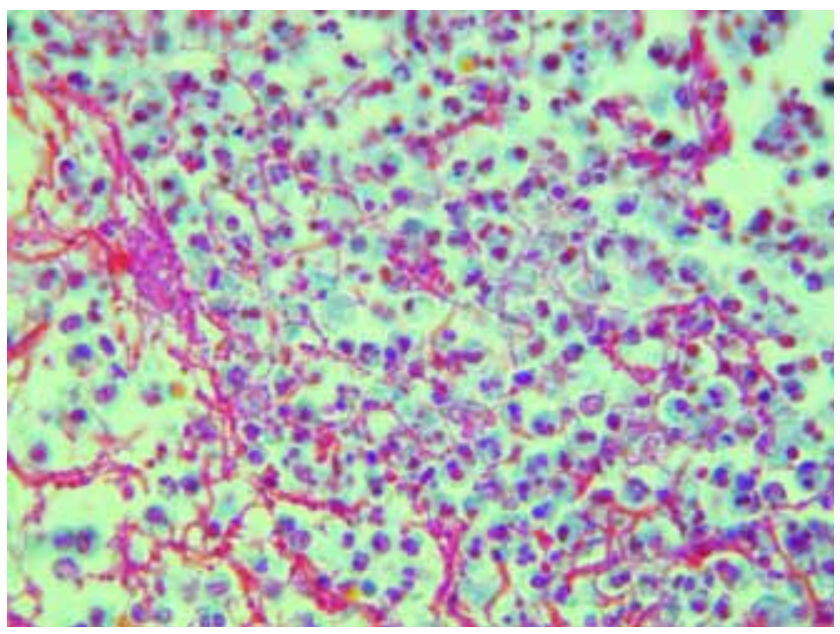

Рис. 1. Полиморфно-ядерные лейкоциты расположены в сети "молодого" (до 24 ч) фибрина. Окраска MSB; × 200

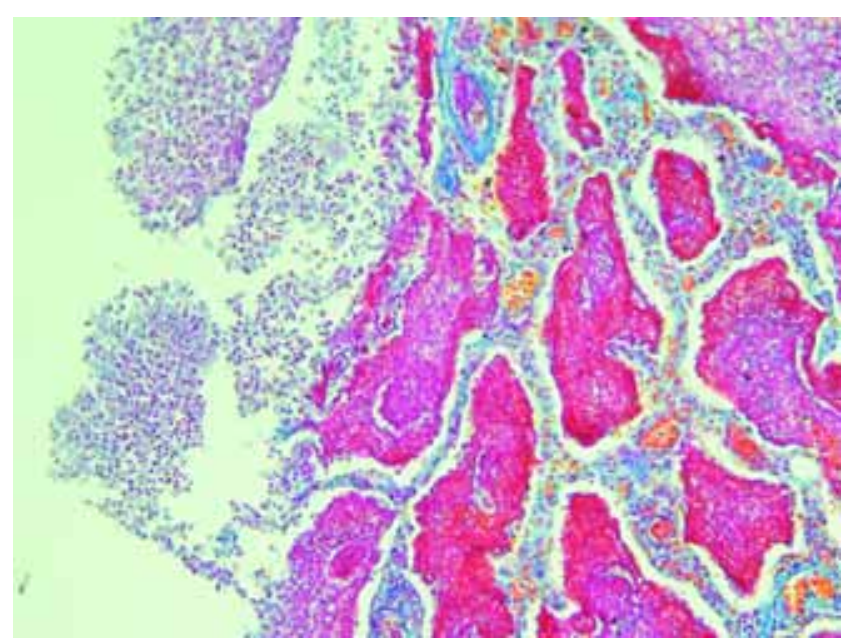

Рис. 2. Острый абсцесс легкого. Ограничение зоны деструкции "молодым" фибрином (до 48 ч). Микроциркуляторное русло свободно. Окраска MSB; × 200

ные волокна, а также обрывки эластических волокон. В стенках капилляров и альвеолярных перегородок выявлялись некротические и некробиотические изменения (рис. 2).

Воспалительный клеточный инфильтрат содержал 60,82 $\pm 6,91 \%$ нейтрофилов, 33,28 $\pm 3,07 \%$ макрофагов и $3,51 \pm 0,51 \%$ лимфоцитов (таблица).

Сосуды микроциркуляторного русла характеризовались полнокровием, не имели признаков фибринообразования, лишь на отдельных участках на поверхности лейкоцитов определялась нежная сеть "молодого" фибрина. Наблюдалось формирование микрополостей вокруг макрофагов и нейтрофилов, отграниченных друг от друга тонкими прослойками "свежего" и "молодого" фибрина. Факт свободного расположения фагоцитирующих клеток является очевидно значимым. У них отмечена относительная "свобода" расположения, рецепторы не блокированы фибрином, а значит, есть возможность развития полноценных репаративных реакций с максимальной тенденцией сохранения анатомических структур (рис. 3). Клеточная реакция была достаточно выра-

Таблица

Состав воспалительного клеточного инфильтрата

\begin{tabular}{l|c|c|c|}
$\begin{array}{l}\text { Количественный состав } \\
\text { клеточных популяций }\end{array}$ & 1 -я группа & 2 -я группа & 3 -я группа \\
$\begin{array}{l}\text { Нейтрофилы } \\
\text { функционально }\end{array}$ & $60,82 \pm 6,91$ & $56,02 \pm 5,18$ & $64,82 \pm 4,80$ \\
$\begin{array}{l}\text { активные } \\
\text { функционально }\end{array}$ & $82,10 \pm 9,69$ & $58,78 \pm 7,03$ & $65,00 \pm 6,28$ \\
$\begin{array}{l}\text { неактивные } \\
\text { Макрофаги }\end{array}$ & $10,08 \pm 1,03$ & $35,71 \pm 6,21$ & $34,37 \pm 3,37$ \\
$\begin{array}{l}\text { функционально } \\
\text { активные }\end{array}$ & $33,28 \pm 3,07$ & $44,22 \pm 4,62$ & $34,66 \pm 3,67$ \\
$\begin{array}{l}\text { функционально } \\
\text { неактивные }\end{array}$ & $61,71 \pm 6,97$ & $49,82 \pm 4,37$ & $48,69 \pm 3,8$ \\
\hline $\begin{array}{l}\text { Лимфоциты } \\
\text { функционально }\end{array}$ & $26,91 \pm 3,57$ & $51,00 \pm 4,82$ & $49,36 \pm 6,61$ \\
активные & $3,51 \pm 0,51$ & $0,98 \pm 0,08$ & $1,18 \pm 0,13$ \\
$\begin{array}{l}\text { функционально } \\
\text { неактивные }\end{array}$ & $89,45 \pm 7,54$ & $60,83 \pm 5,47$ & $73,99 \pm 6,47$ \\
& $6,48 \pm 0,86$ & $28,72 \pm 3,57$ & $7,42 \pm 1,23$ \\
\hline
\end{tabular}

Примечание: $p<0,05$ 


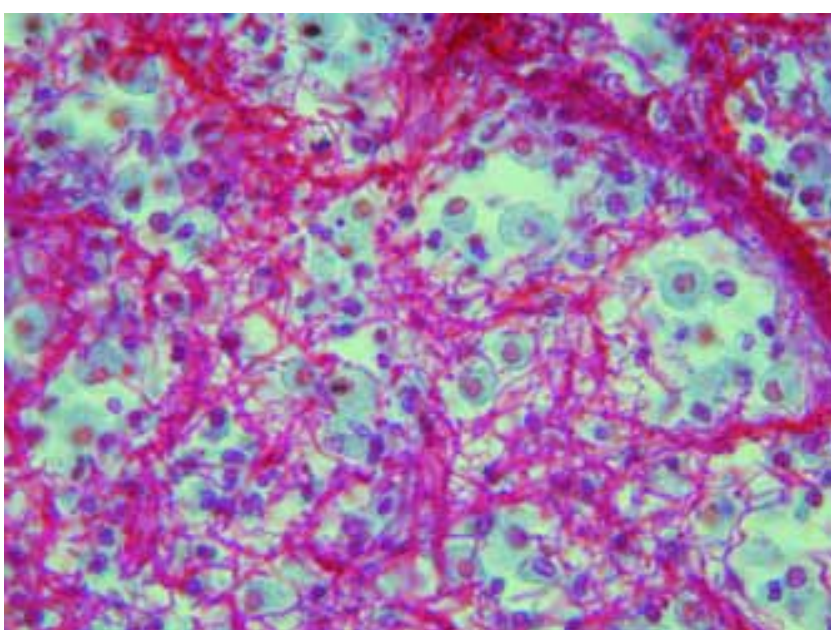

Рис. 3. Клеточная поверхность фагоцитирующих клеток свободна от фибриновых депозитов. Окраска MSB; × 1000

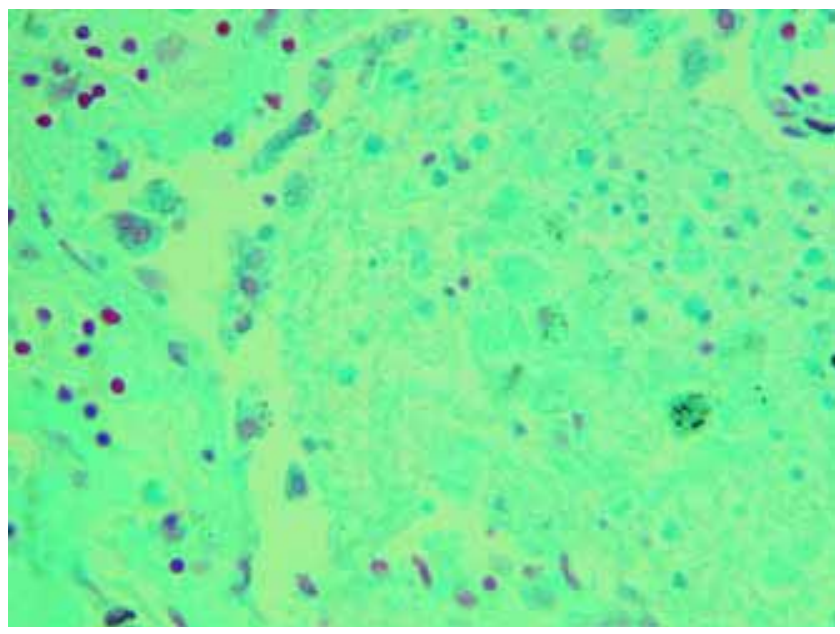

Рис. 4. Свободное расположение фагоцитирующих клеток. Клеточные популяции функционально активны. Окраска по Яцковскому; $\times 600$

женной (рис. 4). Количество функционально-активных макрофагов у данной группы больных составляло $61,71 \pm 6,97 \%$, нейтрофилов $-82,1 \pm 9,69 \%$, лимфоцитов $-89,45 \pm 7,54 \%$ (рис. 5). В ряде случаев в условиях применения лекарственной стимуляции фагоцитарной активности макрофагов и фибринолитиков (использование криоплазменно-антифер-

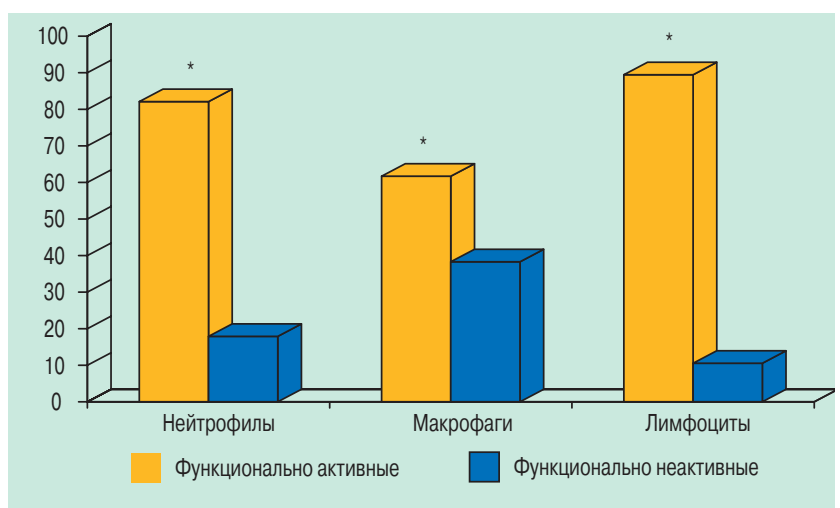

Рис. 5. Функциональная активность клеточных популяций в 1-й группе. Достаточно выраженная клеточная реакция, преобладают функционально активные клетки

Примечание: * $-p<0,001$.

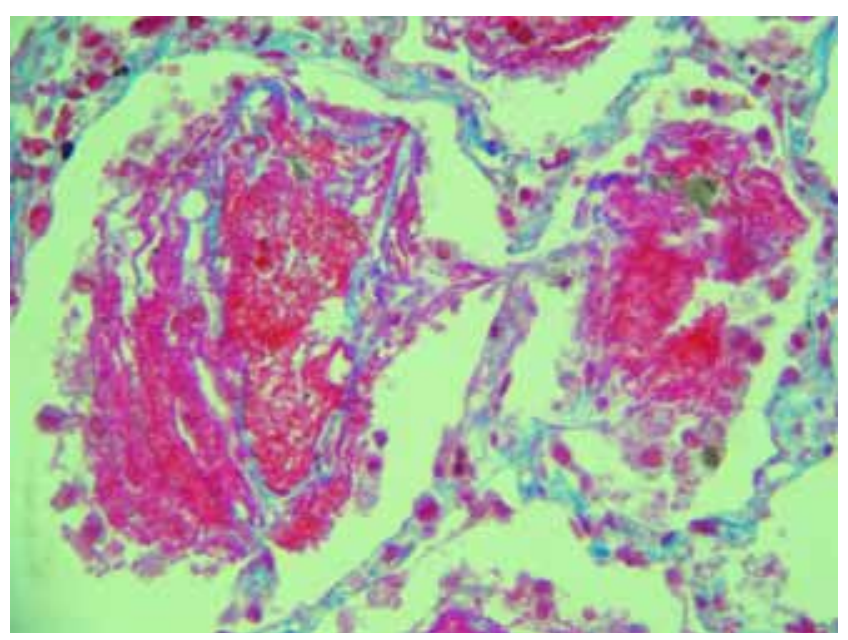

Рис. 6. Распространение фибрина по порам Кона. Лизис фибриновых депозитов. Окраска MSB; × 600

ментной терапии) удалось наблюдать лизис "свежего" и "молодого" фибрина (рис. 6).

В подострый период развития патологического процесса происходило "созревание" фибрина с последующей организацией и разрастанием грануляционной ткани. У 42 больных (36 \% наблюдений) особенности течения патологического процесса заключались в превалировании процессов фибринообразования над лизисом фибрина, обусловленным сниженной функциональной активностью клеточных популяций воспалительного инфильтрата. В его составе определялись умеренные количества нейтрофилов и макрофагов $(56,02 \pm 5,18$ и 44,22 \pm $4,62 \%$ соответственно) и незначительное содержание клеток лимфоцитарного ряда $(0,98 \pm 0,08 \%)$. Клинически для данной группы больных было характерно наличие абсцессов с секвестрацией.

Определяли сравнительно большее количество хаотично ориентированных нитей фибрина, со сроком фибринообразования 24-48 ч. Массивные отложения "молодого" и "созревающего" фибрина замыкали макрофаги и нейтрофилы в своеобразный "фибриновый кокон", в котором клеточные популяции оказывались буквально "вмонтированы" в фиб-

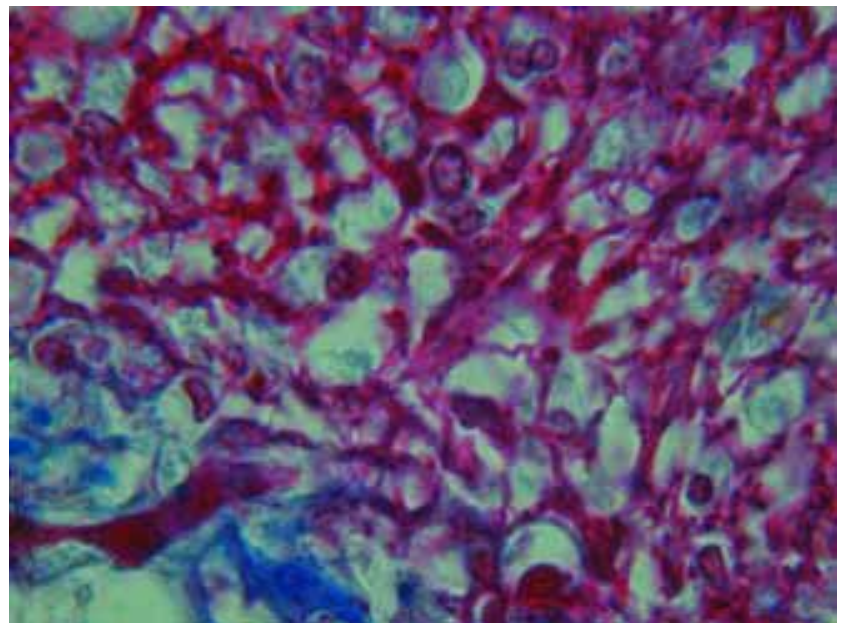

Рис. 7. Макрофаги плотно окружены фибрином. Созревание фибрина (внизу слева). Окраска MSB; × 1000 


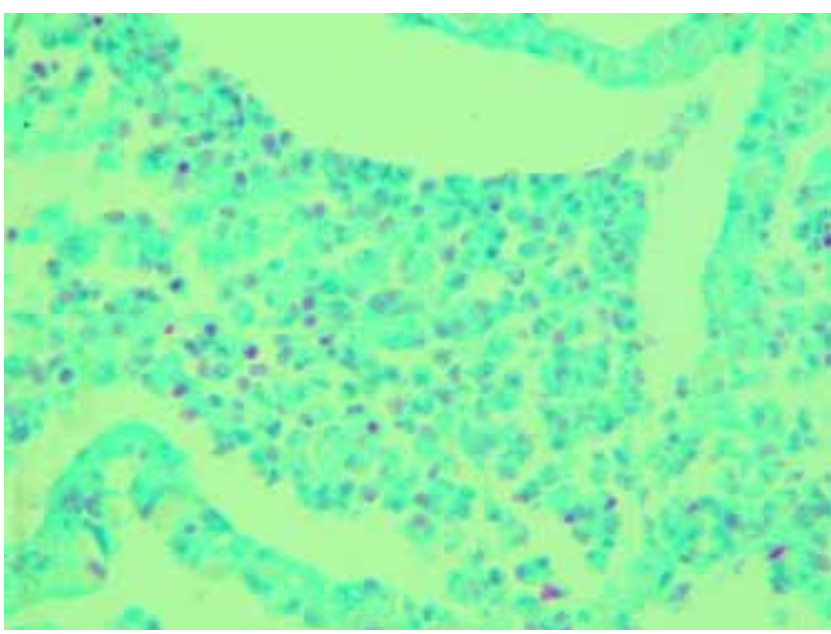

Рис. 8. Снижение функциональной активности клеток, заключенных в "фибриновый кокон". Окраска по Яцковскому; × 600

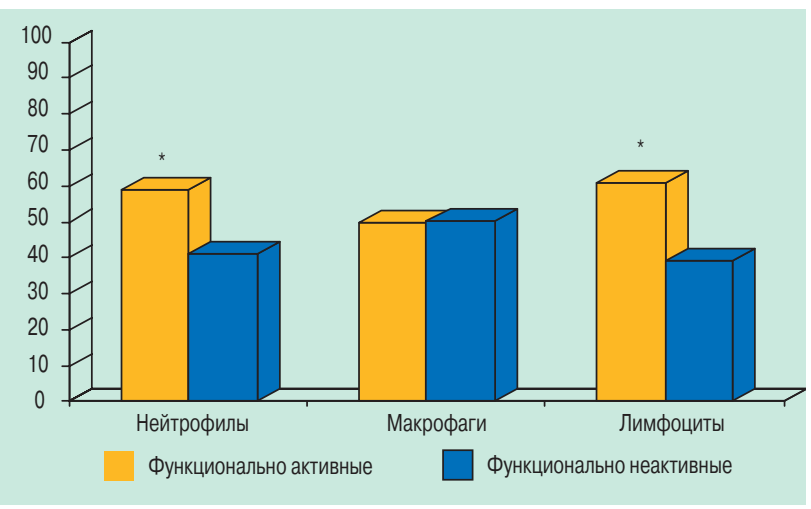

Рис. 9. Снижение функциональной активности клеточных популяций во 2-й группе вследствие инкорпорации в фибриновый кокон Примечание: ${ }^{*}-p<0,001$.

риновые депозиты (рис. 7). Выраженность клеточной реакции при этом была сниженной (рис. 8). Функциональная активность сохранялась у 58,78 \pm 7,03\% нейтрофилов, 49,82 \pm 4,37\% макрофагов и $60,83 \pm$ 5,47 \% лимфоцитов (рис. 9).

Блокирование рецепторов различных клеток путем фибринизации на поверхности их мембран существенно затрудняет выполнение их биологической функции на различных этапах развития абсцессов и гангрен легкого и делает невозможными своевременную элиминацию "свежего" и "молодого" фибрина, его созревание и развитие склеротических изменений, резко снижающих функциональную активность легких. Вместе с тем возможна частичная блокировка рецепторов, в основном макрофагов. В этом случае без проводимого лечения имеет место тенденция к хронизации патологического процесса. При этом в ближайшем будущем возможно развитие как абсцесса, так и пневмофиброза, с последующей тенденцией к карнификации и формированию легочно-сердечной недостаточности.

В сосудах микроциркуляторного русла, артериях и венах отмечалось набухание и слущивание эндотелия на значительном протяжении, массивное отложение фибрина зрелостью от 2-6 до 48-72 ч с нарушением проходимости сосудов на фоне выраженной периваскулярной фибринации тканей. В некоторых

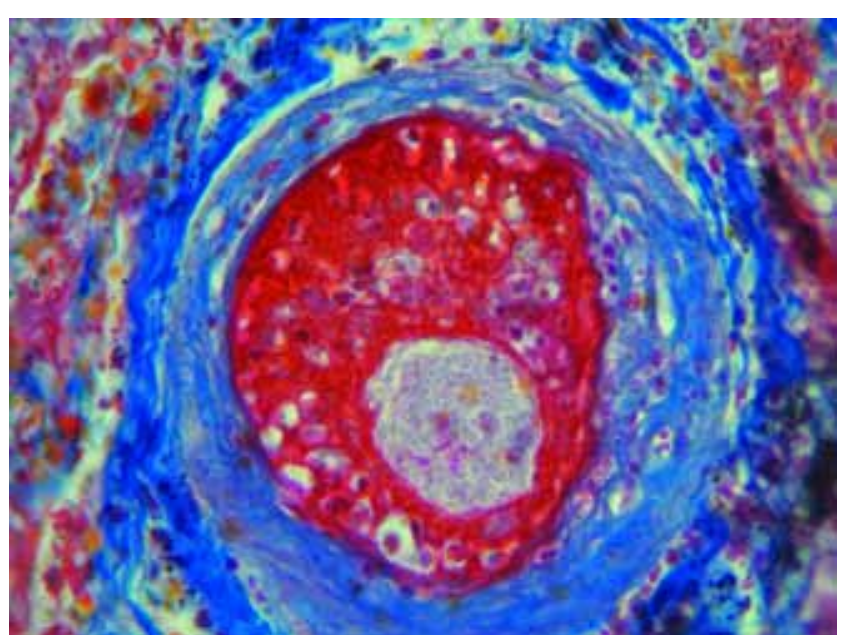

Рис. 10. Инфицированный тромб. Периваскулярная фибринация. Окраска MSB; × 600

случаях в сосудах формировались очаги гнойного тромбоза (рис. 10).

В $28 \%$ наблюдений (32 больных) было характерно обширное, субтотальное и тотальное, часто двустороннее поражение легочной ткани со слабо выраженной тенденцией к отграничению гнойнодеструктивного процесса посредством фибрина. Светооптически определялись обширные зоны деструкции, перемежающиеся с остатками слабо фибринизированной легочной паренхимы.

Гнойный экссудат содержал большое количество некротически и некробиотически измененных нейтрофилов $(64,82 \pm 4,8 \%)$ с умеренным $(34,66 \pm 3,67 \%)$ и незначительным $(1,18 \pm 0,13 \%)$ количеством макрофагов и лимфоцитов, единичные хаотично ориентированные нити, как правило, молодого фибрина (срок фибринообразования - 24-72 ч), единичные обрывки ретикулярных и эластических волокон. Межальвеолярные перегородки были некротизированы.

Характерной была слабая тенденция к отграничению очага гнойно-деструктивного процесса от окружающих тканей (рис. 11): граница между зоной абсцедирования и легочной паренхимой была стер-

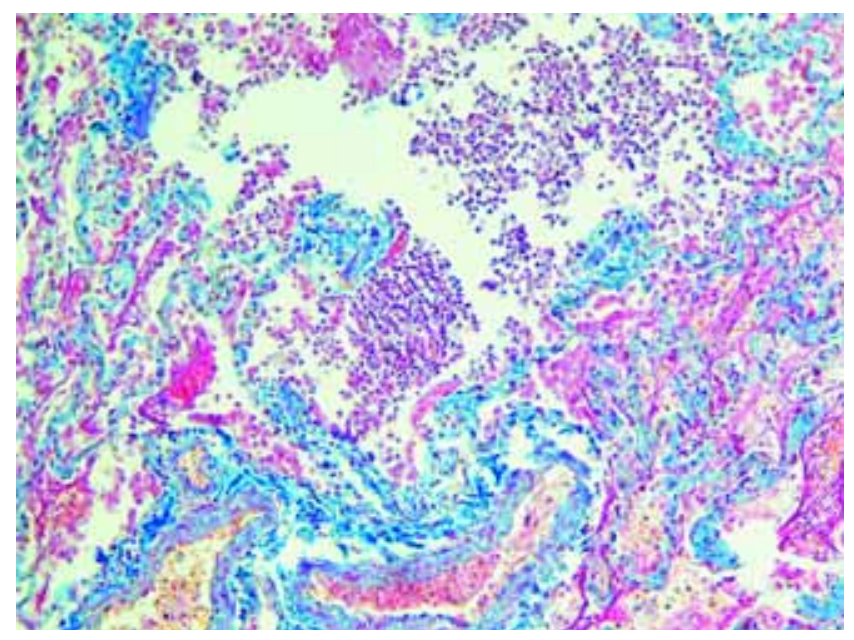

Рис. 11. Гангрена легкого с разрушением крупного бронха и большей части паренхимы. Сосуды свободны от фибриновых депозитов. Окраска MSB; × 200 


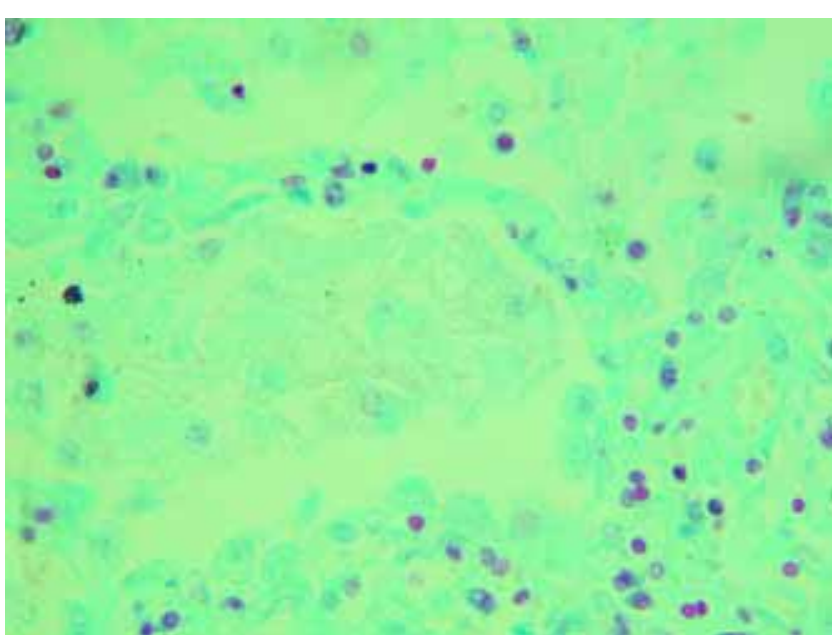

Рис. 12. Снижение функциональной активности фагоцитирующих клеток. Окраска по Яцковскому; × 600

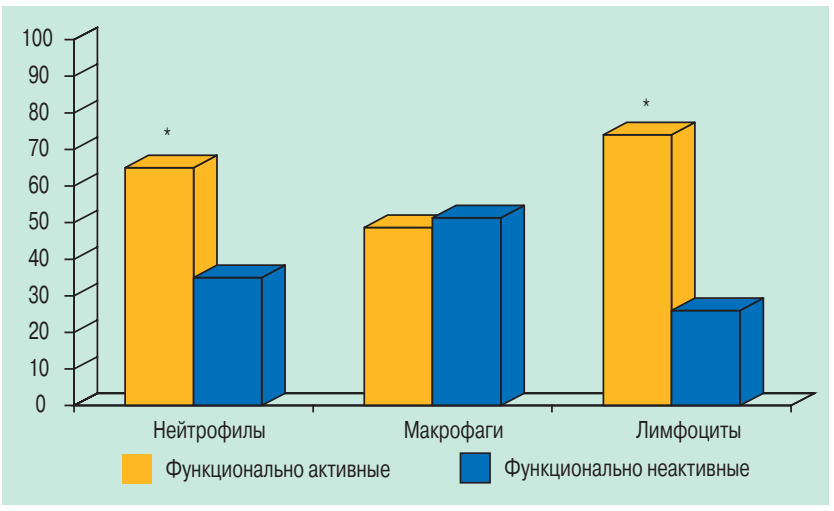

Рис. 13. Снижение функциональной активности нейтрофилов и макрофагов в 3-й группе на фоне сохраненной активности лимфоцитов

Примечание: * $-p<0,001$.

той, процессы фибринообразования были недостаточны, определялось малое или умеренное количество "молодого" и "созревающего" фибрина (24-48 ч). На этом фоне фагоциты (большое количество нейтрофилов и умеренное макрофагов) лежали относительно свободно: "фибриновый кокон" не образовывался, в ряде случаев определялась нежная сеть "молодого" фибрина на поверхности лейкоцитов. Тем не менее функциональная активность нейтрофилов и макрофагов была в значительной степени снижена $(65,0 \pm 6,28$ и 48,69 $\pm 3,8 \%$ соответственно) на фоне сохраненной или повышенной активности лимфоцитов $(73,99 \pm 6,47 \%)$, как видно на рис. 12 и 13.

В динамике отмечена тенденция к периваскулярному и интерстициальному склерозу с наличием фибриновых депозитов различного срока давности (рис. 14). Признаки фибринообразования в сосудах микроциркуляторного русла не обнаружены, лишь в отдельных полях зрения определялась нежная сеть "молодого" фибрина на поверхности эритроцитов и лейкоцитов.

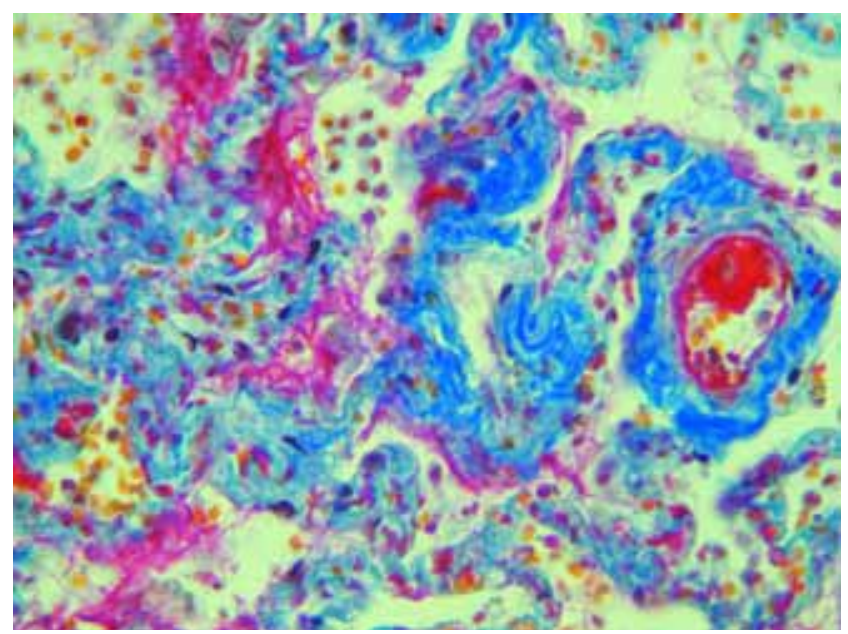

Рис. 14. Периваскулярный и интерстициальный склероз с наличием фибриновых депозитов различного срока давности. Окраска $\mathrm{MSB} ; \times 200$

\section{Заключение}

Наиболее перспективным среди патогистологических изменений в плане положительной динамики развития преобразовательных процессов следует считать вариант с формированием фибринового блока из "молодых" фибриновых депозитов, наличием достаточно выраженной клеточной реакции и отсутствием блокады микроциркуляции. Выявленные структурные закономерности клеточно-стромальных преобразований должны учитываться патологами при составлении развернутого заключения о характере обнаруженных явлений в очаге гнойной деструкции, что будет способствовать выработке правильных тактических приемов в лечении данной патологии.

\section{Литература}

1. Логвиненко А.С. Острые инфекционные деструкции легких в терапевтической клинике. Сибирский консилиум 2004; 2 (32): 39-43.

2. Сильвестров В.П. Хронический бронхит. Клиническая медицина 1990; 10: 105-111.

3. Яковлев С.В. Антибактериальная терапия осложненной пневмонии. Consilium Medicum 2001; 3: 1-9.

4. Путов Н.В., Федосеев Г.Б. Руководство по пульмонологии. 2-е изд. Л.: Медицина; 2000.

5. Муромский Ю.А., Сазонов А.М. (ред.). Гнойные заболевания легких: республиканский сборник научных трудов. М.: МОНИКИ им. М.Ф.Владимирского; 1987.

6. Шойхет Я.Н., Баркаган З.С., Дуков Л.Г. и др. Комплексное лечение острых абсцессов и гангрен легких. В кн.: Актуальные вопросы реабилитации больных с патологией органов дыхания: Тезисы конференции врачейпульмонологов Сибири и Дальнего востока. Барнаул; 1989. 234-236.

7. Яиковский А.Н. Метод оценки функциональной активности клеточных ядер. Арх. анат. 1987; 1: 76-79.

8. Abramoff M.D., Magelhaes P.J., Ram S.J. Image Processing with ImageJ. Biophoton. Int. 2004; 11 (7): 36-42. 